\title{
Pengaruh keterampilan sosial terhadap kepercayaan diri siswa terisolir
}

\author{
Erika Putri Martono ${ }^{1 *}$, Solihatun Solihatun'), Wahyu Eka Prasetyaningtyas ${ }^{3)}$ \\ 1,2,3) Universitas Indraprasta PGRI \\ *) erikaputrimartono02@gmail.com
}

\begin{abstract}
Article History: Received: 03/08/2021; Revised: 19/10/2021: Accepted: 22/10/2021 Published: 30/10/2021.
\end{abstract}

How to cite: Martono, E.P., Solihatun, S., \& Prasetyaningtyas, W.E. (2021). Pengaruh keterampilan sosial terhadap kepercayaan diri siswa terisolir. Orien: Cakrawala Ilmiah Mahasiswa, 1(2), pp. 167-174. DOI: 10.30998/ocim.v1i2.5262

\section{(c) (i) This is an open} access article distributed under the Creative Commons 4.0 Attribution License, which permits unrestricted use, distribution, and reproduction in any medium, provided the original work is properly cited. (c) 2021, Martono, Solihatun, \& Prasetyaningtias.

\begin{abstract}
Abstrak: keterampilan sosial merupakan kemampuan seseorang dalam melakukan interaksi dengan orang lain guna membangun hubungan yang baik, tanpa adanya keterampilan sosial dalam diri seseorang maka akan timbul permasalahan seperti halnya tiak memiliki kepercayaan diri. Tujuan penelitian ini adalah untuk mengetahui adakah pengaruh antara keterampilan sosial dengan kepercayaan diri siswa terisolir. Metode penelitian menggunakan kuantitatif analisa korelasional. Sampel yang diambil berjumlah 19 siswa terisolir kelas VIII dari keseluruhan populasi 123 siswa. Alat pengumpulan data yang digunakan dalam penelitian ini adalah sosiometri dan kuesioner. Teknik analisa data mengunakan teknik regresi linear sederhana. Hasil penelitian menunjukan adanya pengaruh keterampilan sosial dengan kepercayaan diri siswa terisolir. Memiliki besar nilai 12.789, dengan nilai signiikansi sebesar 0,002 <0,05, yang artinya terdapat pengaruh antara keterampilan sosial dengan kepercayaan diri siswa terisolir.
\end{abstract}

Kata Kunci: keterampilan sosial, kepercayaan diri

Abstract: social skills are a person's ability to interact with other people in order to build good relationships, without social skills in a person, problems will arise such as not having self-confidence. The purpose of this study was to determine whether there was an influence between social skills and self-confidence of isolated students. The research method uses quantitative correlational analysis. The samples taken were 19 isolated class VIII students from a total population of 123 students. Data collection tools used in this study were sociometric and questionnaire. The data analysis technique used a simple linear regression technique. The results showed that there was an influence of social skills with isolated students' self-confidence. Has a large value of 12,789 , with a significance value of $0.002<0.05$, which means that there is an influence between social skills and self-confidence of isolated students.

Keywords: social skills, self-confidence

\section{Pendahuluan}

Pendidikan adalah usaha sadar dan terencana untuk mewujudkan suasana belajar dan proses pembelajaran agar siswa secara aktif mengembangkan potensi dirinya untuk memiliki kekuatan spiritual keagamaan, pengendalian diri, kepribadian, kecerdasan, akhlak mulia, serta keterampilan yang diperlukan dirinya, masyarakat, bangsa dan negara menurut Undangundang No. 20 tahun 2003 Bab 1 Pasal 1 tentang Sistem Pendidikan Nasional (Indonesia, 2003). Menurut Sukmadinata (2005) pendidikan merupakan suatu pembelajaran yang menciptakan 
interaksi sosial antara pendidik dengan siswa untuk mencapai tujuan yang berlangsung dalam lingkungan sekolah. Seorang pendidik berkewajiban untuk memberikan, menanamkan, menumbuhkan nilai-nilai positif pada siswa untuk menumbuh kembangkan sendiri nilai nilai yang ada pada dirinya dilingkungan sekolah.

Pada dasarnya pendidikan dasar merupakan salah satu masa peralihan pada masa kanakkanak (6-9 tahun), dan kanak-kanak akhir (10-12 tahun). Desmita (dalam Rosita, 2013), dan menuju ke masa remaja merupakan masa transisi atau peralihan dari masa anak-anak menuju masa dewasa. Secara umum masa remaja dibagimenjadi dua bagian.. Pertama, masa remaja awal (early adolescence) kira-kira sama dengan masa sekolah menengah pertama dan mencakup kebanyakan pubertas. Kedua, masa remaja akhir (late adolescence) menunjukkan pada kira-kira setelah usia 15 tahun (Santrock, 2003).

Pada masa ini individu mengalami berbagai perubahan, baik fisik maupun psikis serta kognitif yang kini mulai mampu berfikir abstrak seperti halnya orang dewasa. Pada periode ini pula, remaja mulai melepaskan diri secara emosional dari orang tua dalam rangka mempersiapkan peran sosial yang selanjutnya sebagai orang dewasa.

Keterampilan sosial remaja dapat berpengaruh besar terhadap pembentukan tingkah laku remaja. Untuk itu remaja di tuntut mampu menentukan sikap serta reaksi yang pantas sesuai dengan remaja seuisanya. Sementara remaja dituntut harus bisa berinteraksi dengan baik dalam menghadapi kondisi lingkungannya, yaitu beradaptasi. Tetapi tidak semua remaja bisa melakukannya dengan baik. Hal ini mengakibatkan remaja merasa kesepian dan mengisolasikan diri mereka dalam kesendirian. Beberapa remaja merasa kesepian karena mereka memiliki kebutuhan yang kuat akan ke intiman, namun belum memiliki keterampilan sosial yang baik atau kematangan hubungan untuk memenuhi kebutuhan tersebut (Santrock, 2003:353).

Salah satu dampak dari kurang baiknya adaptasi remaja yang cukup penting mempengaruhi munculnya kenakalan remaja adalah rendahnya keterampilan sosial remaja. Untuk itu, remaja perlu mengembangkan keterampilan sosialnya agar tetap bisa beradaptasi dengan lingkungannya serta memenuhi tuntutan tugas perkembangannya. Keterampilan sosial adalah kemampuan seseorang untuk berkenalan, menyesuaikan diri, serta mengatasi masalah dan berinteraksi dengan lingkungannya (Rosdianah, 2009).

Keterampilan sosial (social skills) mempunyai kedudukan yang sangat penting dalam kehidupan. Keterampilan social akan memberikan citra kualitas kepribadian seseorang dalam berinteraksi dengan orang lain. Tanpa memiliki keterampilan ini, seseorang tidak akan mulus dalam berinteraksi dengan orang lain, sehingga hidupnya kurang harmonis (Sangsoko, 2001). Elksnin \& Elksnin (1999) mengidentifikasi keterampilan sosial dengan beberapa ciri, yaitu: perilaku interpersonal, perilaku yang berhubungan dengan diri sendiri, perilaku yang berhubungan dengan kesuksesan akademis, peer acceptance, keterampilan komunikasi. Akan tetapi tidak semua individu memiliki rasa kepercayaan diri yang cukup, melainkan masih banyak individu yang masih merasakan minder, malu serta sungkan terhadap poses belajar maupun bersosialisasi.

Menurut Yusuf (2008) masa remaja merupakan masa stress dalam perjalanan hidup seseorang. Bagi remaja yang dikucilkan dari teman sebayanya mereka berarti stress, fustasi, dan kesedihan. Pada masa remaja, pergaulan dengan teman-teman jauh lebih banyak dari pada dengan keluarga. Menurut Thantawy dalam Balqis (2013) percaya diri adalah kondisi mental atau psikologis diri seseorang yang memberi keyakinan kuat pada dirinya untuk berbuat atau melakukan suatu tindakan. 
Davies (dalam Burson, 2018) menjelaskan bahwa kepercayaan diri adalah sikap positif seseorang individu untukmenerima dirinya sendiri, berani mengambil resiko, dan kepercayaan akan potensi diri. Maka oleh sebab itu seorang individu yang masih berada di bangku sekolah harus bisa memiliki rasa kepercayaan diri yang tinggi dikarnakan dengan adanya rasa kepercayaan diri yang tinggi dapat meningkatkan pula kepercayaan diri yang dimilikinya baik di lingkungan sosialnya maupun belajarnya.

Lie (dalam Burson, 2018) Ciri-ciri perilaku yang mencerminkan kepercayaan diri yaitu: yakin kepada diri sendiri, tidak bergantung kepada orang lain, tidak ragu-ragu, merasa diri berharga, tidak menyombongkan diri, serta memiliki keberanian untuk bertindak. Lauster (dalam Kusrini \& Prihartanti, 2014) mengemukakan ada lima aspek yang mempengaruhi kepercayaan diri seseorang, yaitu : keyakinan akan kemampuan diri, maksudnya sikap positif seseorang tentang dirinya, optimisme yaitu sikap positif seseorang yang selalu berpandangan baik dalam menghadapi segala hal, objektif yaitu sikap seseorang yang memandang segala sesuatu sesuai dengan kebenaran yang semestinya, bertanggung jawab, yaitu kesediaan seseorang untuk menanggung segala sesuatu yang telah menjadi konsekuensinya, rasional dan realitas, yaitu kemampuan menganalisa masalah atau kejadian dengan menggunakan pikiran yang masuk akal.

Penelitian ini sejalan dengan penelitian terdahulu yang dilakukan oleh (Dan, Nugget, \& Rinuak, 2020), dengan judul penelitian yang berjudul "Pengaruh konsep diri, percaya diri, dan keterampilan interaksi sosial terhadap prestasi akademik" dari penelitian didapatkan menunjukan rata-rata skor konsep diri terhadap variabel presatsi akademik sebesar 0,139 dengan sig 0,019<0,05. Artinya ada kontribusi konsep diri terhadap prestasi akademik sebesar 0,139 atau 13,9\% dengan signifikansi 0,000. Kontribusi variabel kepercayaan diri terhadap prestasi akademik sebesar 0,302 dengan sig 0,000. Artinya, ada kontribusi variabel kepercayaan diri terhadap prestasi akademik sebesar 0,302 atau $30,2 \%$ pada signifikansi 0,000 . Kontribusi variabel interaksi sosial terhadap prestasi akademik sebesar 0,253 pada sig 0,000<0,05. Artinya, ada kontribusi interaksi sosial terhadap prestasi akademik sebesar 0,253 atau 25,3\% pada signifikansi 0,000 .

Penelitian terdahulu mengenai keterampilan sosial siswa terisolir di lakukan oleh (Solihatun \& Oktasari, 2018), dengan judul penelitian "gambaran keterampilan sosial siswa terisolir serta implikasinya dalam pelayanan bimibingan dan konseling" dari penelitain tersebut menunjukan rata-rata skor aspek keterampilan sosial siswa terisolir di SMKN 20 Cilandak Jakarta Selatan yang berada pada kategori rendah adalah aspek peer acceptance, sebanyak empat orang siswa $(26,7 \%)$, kategori sedang adalah aspek interpersonal, sebanyak tujuh orang siswa $(46,7)$ dan kategori tinggi adalah aspek keterampilan komunikasi, sebanyak tujuh orang siswa $(46,7 \%)$.

Fakta yang muncul di SMP Jayakarta hasil wawancara dengan salah satu guru pengajar Ibu Dwi menyatakan bahwa, dalam keterampilan sosial yang dimiliki siswa-siswi di SMP Jayakarta tersebut bisa dibilang masih terdapat beberapa siswa yang memiliki keterampilan sosial yang bisa dikatakan cukup atau rendah, dikarenakan masih terdapat beberapa siswa yang bisa terbilang sebagai siswa yang diabaikan oleh sebayanya, serta terdapat individu yang tidak diterima dalam sebuah kelompok, seperti halnya saat individu diminta untuk membuat suatu kelompok belajar akan tetapi teman-temannya menolak untuk individu tersebut bergabung dalam kelompoknya, serta saat pendapatnya disampaikan tidak didengarkan oleh temantemannya, maka hal tersebutlah yang dapat membuat siswa juga merasa kurang percaya diri teradap apa yang dilakukannya. 
Namun dalam segi kepercayaan diri yang dimiliki oleh siswa-siswi SMP Jayakarta tersebut masih ada beberapa siswa yang kurangnya percaya diri, misalnya dalam segi belajar masih ada beberapa siswa yang masih malu, ragu untuk mengungkapkan baik pendapatnya maupun yang ingin ditanyakan di dalam kelas saat proses pembelajaran belangsung, dan hal tersebut mengakibatkan siswa menjadi kurang memiliki motivasi dalam belajarnya serta akan mempengaruhi prestasi belajarnya. Sehingga lebih lanjut keterampilan sosial dan interaksi hubungan sosial dengan kepercayaan diri siswa pun akhirnya berhubungan erat dengan motivasi berprestasi belajarnya (Oktasari, Solihatun, \& Monalisa, 2018).

Biasanya siswa-siswi yang tidak memiliki kepercayaan diri ini lebih memilih untuk banyak diam atau tidak berpendapat sekalipun dikarnakan ia merasa bahwa jika ia berpendapat maka apa yang akan ia sampaikan baik kepada temannya, guru atau orang lain salah. Oleh sebab itu dari beberapa permasalahan di atas maka peneliti tertarik untuk meneliti tentang pengaruh keterampilan sosial terhadap kepercayaan diri siswa terisolir. Masalah dalam penelitian ini adalah adakah pengaruh keterampilan sosial terhadap kepercayaan diri siswa terisolir?. Tujuan penelitian ini untuk mengetahui ada tidaknya pengaruh keterampilan sosial terhadap kepercayaan diri siswa terisolir pada siswa. Hasil penelitian ini diharapkan dapat menambah dan memperkaya hasil penelitian yang sudah ada, dan sebagai acuan serta memberi informasi untuk siswa, guru Bimbingan dan Konseling (BK) dalam merumuskan strategi layanan yang tepat dan efektif guna mengatasi permasalahan siswa mengenai keterampilan sosial dan kepercayaan diri siswa.

\section{Metode}

Metode penelitian yang digunakan dalam penelitian ini adalah metode kuantitatif dengan desain penelitian analisa korelasional. Penelitian dilakukan di SMP Jayakarta. Populasi dalam penelitian ini merupakan siswa kelas VIII dengan jumlah 123 siswa. Sampel dalam penelitian ini menggunakan hasil dari penyebaran sosiometri yang telah diisi oleh 123 siswa. Hasil sosiometri terdapat 19 siswa yang terisolir, maka ditetapkan sumber data sebanyak 19 siswa terisolir di keseluruhan kelas VIII. Instrumen yang digunakan dalam penelitian ini berupa sosiometri dan kuesioner. Kuesioner dalam penelitian ini sudah lulus validasi dan dinyatakan valid oleh dosen pembimbing dan dosen ahli judgement. Data yang diambil dalam penelitian ini kemudian dihitung menggunakan cara manual dengan bantuan microsoft excel dan menggunakan bantuan software SPSS ver. 16.0.

\section{Hasil dan Diskusi}

Penelitian ini bertujuan untuk mengetahui pengaruh keterampilan sosial terhadap kepercayaan diri siswa terisolir di SMP Jayakarta. Selain itu juga untuk memberi gambaran tentang keterampilan sosial danke percayaan diri. Terlebih bagaimana pentingnya keterampilan sosial bagi siswa untuk meningkatkan kepercayaan dirinya. Seperti yang telah dijelaskan oleh (Cartledge. G. \& Milburn, 1995) juga menjelaskan social skills are ones or society member ability in establishing relationship with others and his problem solving ability with which a harmonies society can be achieved. Dengan kata lain, keterampilan sosial merupakan kemampuan seseorang atau warga masyarakat dalam mengadakan hubungan dengan orang lain dan kemampuan memecahkan masalah sehingga memperoleh adaptasi yang harmonis di masyarakat.

Berdasarkan hasil pengolahan kuesioner keterampilan sosial maka didapatkan hasil sebagai berikut: 
Tabel 1. Faktor Pembentuk Utama Keterampilan Sosial Siswa

\begin{tabular}{lcccc}
\hline \multicolumn{1}{c}{ Aspek } & Skor Total Aspek & $\begin{array}{c}\text { Skor Total } \\
\text { Variabel }\end{array}$ & Hasil & Persentase \\
\hline $\begin{array}{l}\text { Perilaku interpersonal } \\
\begin{array}{l}\text { Perilaku yang berhubungan } \\
\text { dengan diri sendiri }\end{array}\end{array}$ & 470 & & 0,231 & $23,10 \%$ \\
$\begin{array}{l}\text { Perilaku yang berhubungan } \\
\text { dengan akademis }\end{array}$ & 165 & 2028 & 0,081 & $8,10 \%$ \\
$\begin{array}{l}\text { Peer apcceptance } \\
\text { Keterampilan komunikasi }\end{array}$ & 710 & & 0,35 & $35 \%$ \\
\hline
\end{tabular}

Sumber: Diolah dari data hasil penelitian, 2021

Berdasarkan tabel 1 maka dapat dimaknai bahwa aspek yang menjadikan siswa memiliki keterampilan sosial yang rendah pada kategori perilaku yang berhubungan dengan diri sendiri dengan persentase sebesar 8,10\%. Disusul oleh keterampilan komunikasi 10,70\%, peer acceptance $22,90 \%$, perilaku interpersonal $23,10 \%$, dan yang tertinggi perilaku yang berhubungan dengan akademis sebesar 35\%. Selanjutnya berdasarkan hasil pengolahan kuesioner kepercayaan diri maka diperoleh hasil sebagai berikut:

Tabel 2. Faktor Pembentuk Utama Variabel Kepercayaan Diri

\begin{tabular}{lcccc}
\hline \multicolumn{1}{c}{ Aspek } & Skor Total Aspek & $\begin{array}{c}\text { Skor Total } \\
\text { Variabel }\end{array}$ & Hasil & Persentase \\
\hline Keyakinan & 224 & & 0,153 & $15,30 \%$ \\
Optimisme & 474 & & 0,325 & $32,50 \%$ \\
Objektif & 165 & 1456 & 0,113 & $11,30 \%$ \\
Bertanggung jawab & 224 & & 0,153 & $15,30 \%$ \\
Rasional dan Realitas & 218 & & 0,253 & $25,30 \%$ \\
\hline
\end{tabular}

Sumber: Diolah dari data hasil penelitian, 2021

Berdasarkan tabel 2 maka dapat dimaknai bahwa aspek yang menjadikan siswa memiliki kepercayaan diri yang rendah pada katagori objektif dengan presentase sebesar $11,30 \%$. Disusul dengan aspek keyakinan dan bertanggung jawab sebesar 15,30\%, rasional dan realitas 25,30\%, dan yang tertinggi optimisme $32,50 \%$. Hasil penelitian ini secara keseluruhan dapat disimpulkan bahwa aspek keterampilan sosial berada pada katagori rendah dengan aspek perilaku yang berhubungan dengan diri sendiri, yang artinya, keterampilan sosial siswa terisolir terjadi karena siswa tidak dapat mengatur diri sendiri dalam situasi sosial, seperti yang dijelaskan oleh David \& Johnson (dalam Andi \& Monepa, 2019) keterampilan sosial merupakan pengamatan tentang perilaku manusia dan proses antarpribadi, kemampuan memahami perasaan, sikap, motivasi, orang lain tentang apa yang dikatakan dan dilakukannya, dan kemampuan untuk berkomunikasi dengan jelas dan efektif serta kemampuan membangun hubungan yang efektif dan koperatif.

Aspek kepercayaan diri yang berada pada kategori rendah dengan aspek objektif, yang artinya keterampilan sosial siswa terisolir terjadi karena adanya pandangan yang tidak objektif terhadap suatu masalah yang menyebabkan siswa menjadi tidak percaya diri. Lauster (dalam Widyaningtyas \& Farid, 2015) menyatakan bahwa self-confidence merupakan suatu sikap atau perasaan yakin atas kemampuan diri sendiri sehingga orang yang bersangkutan tidak terlalu cemas dalam tindakan-tindakannya, dapat merasa bebas untuk melakukan hal-hal yang 
disukainya dan bertanggung jawab atas perbuatannya, hangat dan sopan dalam berinteraksi dengan orang lain, dapat menerima dan menghargai orang lain, memiliki dorongan untuk berprestasi serta dapat mengenal kelebihan dan kekurangannya.

Ignoffo (dalam Widyaningtyas \& Farid, 2015)secara sederhana mendefenisikan selfconfidence berarti memiliki keyakinan terhadap diri sendiri. Hurlock (dalam Widyaningtyas \& Farid, 2015) pada masa pubertas atau masa remaja awal terdapat gejala yang disebut gejala negative phase, istilah phase menunjukkan periode yang berlangsung singkat. Negative berarti bahwa individu mengambil sikap anti terhadap kehidupan atau kehilangan sifat-sifat baik yang sebelumnya sudah berkembang. Gejala ini banyak terjadi pada remaja awal, diantaranya keinginan untuk menyendiri, berkurang kemampuan untuk bekerja, kegelisahan, kepekaan perasaan, pertentangan sosial dan rasa kurang percaya diri (lack of self-confidence). Dari beberapa gejala negative phase di atas yang paling menonjol dialami masa remaja adalah rasa kurang percaya diri (lack of self-confidence).

Selanjutnya untuk mempengaruhi seberapa besar pengaruh keterampilan sosial dengan kepercayaan diri peneliti menggunakan spss dengan versi 16.0, sebagai berikut:

Tabel 3. Pengujian Regresi

ANOVA $^{\mathrm{b}}$

\begin{tabular}{llcccrr}
\multicolumn{1}{c}{1} & Sum of Squares & $d f$ & Mean Square & $F$ & Sig. \\
Regression & 278.918 & 1 & 278.918 & 12.789 & $.002^{\mathrm{a}}$ \\
Residual & 370.766 & 17 & 21.810 & & \\
Total & 649.684 & 18 & & &
\end{tabular}

Berdasarkan hasil tabel uji regresi linear sederhana diatas dapat dijelaskan bawa memiliki besarnya nilai hitung sebesar 12.789 dengan tingkat signiikasi sebesar $0.002<0,005$, yang berarti bahwa terdapat pengaruh antara vaiabel keterampilan sosial dengan kepercayaan diri yang dimiliki siswa terisolir di SMP Jayakarta. Berdasarkan dari penjelasan di atas dapat disimpulkan bahwa keterampilan sosial siswa terisolir yang rendah harus memiliki perhatian yang lebih dari guru BK, dan pihak-pihak pengajar di SMP Jayakarta guna untuk meningkatkan kepercayaan diri peserta didik serta mengurangi adanya siswa terisolir yang terjadi pada sekolah.

\section{Simpulan}

Berdasarkan penelitian yang dilakukan oleh peneliti tentang "Pengaruh Keterampilan Sosial Terhadap Kepercayaan Diri Siswa Terisolir" peneliti mendapatkan hasil dari kuesioner, sosiometri yang digunakan dalam pengumpulan data dapat diketahui bahwa terdapat pengaruh antara keterampilan sosial terhadap kepercayaan diri ini juga dikategorikan signifikansi sebesar $0,002<0,05$ dengan nilai hitung sebesar 12.789. Sedangkan yang lainnya dipengaruhi oleh aspek lain. Beberapa aspek lainnya mempengaruhi keterampilan sosial adalah keyakinan, optimisme, objektif, bertanggung jawab, dan rasional dan realitas. Dan ini disimpulkan maka diketahui adanya pengaruh keterampilan sosial terhadap kepercayaan diri siswa terisolir. Semoga tulisan ini mampu dijadikan sebagai sumber referensi dalam pengembangan keilmuan Bimbingan dan Konseling di Indonesia. 


\section{Ucapan Terima Kasih}

Terima kasih kepada semua pihak yang telah membantu dalam pelaksanaan penelitian dan penulisan artikel ini, kepada dosen pembimbing Solihatun, M.Pd., Kons., dan Wahyu Eka Prasetyaningtias, M.Pd., pihak SMP Jayakarta yang telah membantu dalam melaksanakan penelitian, kedua orang tua, dan rekan-rekan seperjuangan.

\section{Daftar Rujukan}

B. Hurlock, E. (2007). Psikologi Perkembangan Pendekatan Sepanjang Rentan (Edisi 8; dr. Med. Metasari Tjandrasa, ed.). Jakata: Penerbit Erlanga.

Burson. Muhammad, D. (2018). Teori sumber daya manusia. Jakarta: Prenamedia Group.

Cartledge. G. \& Milburn, J. F. (1995). Teaching Social Skills to Children \& Youth (Innovative; Massachussetts, ed.). Allyn and Bacon.

Dan, F., Nugget, K., \& Rinuak, I. (2020). Jurnal pendidikan dan keluarga. 12(01), 53-59.

Elksnin \& Elksnin. (1999). Keterampilan Sosial pada Anak Menengah Akhir. (diakses 22 Maret 2018). https://doi.org/http:f4jar.multiply.com/journal/item/191

Ida Rosita. (2013). Efektifitas Bimbingan Kelompok Melalui Permaianan Trasisonal Untuk Meningkatkan Keterampilan Sosial Siswa. Universitas Pendidikan Indonesia. https://doi.org/repository.upi.edu

Indonesia, P. R. (2003). Undang-undang Republik Indonesia nomor 20 tahun 2003 tentang sistem pendidikan nasional. Departemen Pendidikan Nasional.

Kusrini, W., \& Prihartanti, N. (2014). Hubungan Dukungan Sosial dan Keperceyaan Diri dengan Prestasi Bahasa Inggris Siswa Kelas VIII SMP Negeri 6 Boyolali. Jurnal Penelitian Humaniora, 15(2), 131-140.

Lauster. (2002a). The Personality Test. London: Pan Books.

Lauster, P. (2002b). Tes Kepribadian (Edisi Baha; Alih Bahasa: D.H Gulo, ed.). Jakarta: Bumi Aksara.

M. Ignoffo. (1999). Everything You Need to Know About Self Confidence (Revised Ed). New York: The Rosen Publishing Group, Inc.

M. si. A. Andi.Dr \& M.psi. J. M. Monepa. (2019). Keterampilan sosial anak usia dini ( teori dan metode pengembangan). Tasikmalaya: Edu Publisher.

Oktasari, M., Solihatun, S., \& Monalisa, M. (2018). Kontribusi Dukungan Sosial Teman Sebaya terhadap Motivasi Berprestasi Siswa. Biblio Couns: Jurnal Kajian Konseling Dan Pendidikan, 1(1), 22-28. https://doi.org/http://dx.doi.org/10.30596\%2Fbibliocouns.v1i1.1940

Sangsoko, N. R. (2001). Model Pembelajaran Aksi Sosial untuk Pengembangan Nilai-Nilai dan Keterampilan Sosial (Desertasi.). PPS UPI (tidakdiperdagangkan).

Solihatun, S., \& Oktasari, M. (2018). Gambaran Keterampilan Sosial Siswa Terisolir Serta Implikasinya Dalam Pelayanan Bimbingan dan Konseling. Wahana Didaktika, 16(3), 330-337. https://doi.org/http://dx.doi.org/10.31851/wahanadidaktika.v16i3.2108 
174 Pengaruh keterampilan sosial terhadap kepercayaan diri siswa terisolir

Widyaningtyas, D., \& Farid, M. (2015). Pengaruh Experiential Learning Terhadap Kepercayaan Diri Dan Kerjasama Tim Remaja. Persona:Jurnal Psikologi Indonesia, 3(03), 237-246. https://doi.org/10.30996/persona.v3i03.413

\section{Competing interests:}

The authors declare that they have no significant competing financial, professional or personal interests that might have influenced the performance or presentation of the work described in this manuscript. 